\title{
ANALISIS PENERJEMAHAN : STUDI KASUS PADA KEBUTUHAN PENERJEMAH BAGIAN MARKETING PT JIALE INDONESIA TEXTILE JEPARA INDONESIA
}

\author{
Dani Putri Septi Kusumaningtyas; Rizky Ervindio \\ Program Studi D3 Bahasa Mandarin, Universitas Sebelas Maret \\ E-mail: putry_fang89@staff.uns.ac.id; rizkyervin23@gmail.com
}

\begin{abstract}
Abstrak
Seorang penerjemah tidaklah cukup hanya memiliki kompetensi dalam hal penguasaan bahasa sumber dan bahasa sasaran secara baik, namun mengembangkan kompetensi dari pribadi penerjemah juga menjadi peran penting dalam kelancaran proses penerjemahan. Tujuan dari penelitian ini adalah untuk menganalisis dan menjabarkan kebutuhan seorang penerjemah bagian marketing di PT Jiale Indonesia Textile. Kebutuhan penerjemah di penelitian ini fokus pada kebutuhan kompetensi pribadi penerjemah. Metode yang digunakan dalam penelitian ini adalah deskriptif kualitatif, yaitu dengan mendeskripsikan beberapa kebutuhan penerjemahan dari aspek pengembangan kompetensi dan mengklasifikasikan daftar istilah kosakata yang sering digunakan dalam proses penerjemahan bidang industri tekstil di PT Jiale Indonesia Textile. Hasil penelitian ini menunjukkan bahwa ada 3 kebutuhan kompetensi yang perlu dikembangkan oleh seorang penerjemah bagian marketing di PT Jiale Indonesia Textile, yaitu: 1.Kompetensi Domain/Subject Specific; 2.Kompetensi Riset; 3.Kompetensi Transfer dan dalam penelitian inijuga menghasilkan sebuah luaran daftar istilah kosakata yang sering digunakan dalam proses penerjemahan bagian marketing di PT Jiale Indonesia Textile. Daftar istilah kosakata bidang tekstil di perusahaan ini dikelompokkan menurut jenis kata yaitu, adjektiva, noun, dan verba, hal ini bertujuan untuk membantu para calon penerjemah untuk dapat mempelajari dan mempersiapkan terlebih dahulu kompetensi, serta kosa kata apa saja yang dibutuhkan dan dipelajari ketika akan terjun dalam dunia penerjemahan, khususnya pada bidang industri tekstil.
\end{abstract}

Kata kunci: penerjemahan; kebutuhan penerjemah; bagian marketing; kosakata; industri tekstil

\section{A. Pendahuluan}

Tiongkok-Indonesia telah menjalin hubungan diplomatik selama 70 tahun, hubungan dan kerjasama pragmatis yang terjalin antara kedua negara ini berdampak pada bertumbuhnya dunia industri di Indonesia. Kemajuan dari sektor industri inilah yang menjadi peluang seorang penerjemah bahasa asing untuk mengambil peran penting sebagai jembatan komunikasi antar kedua negara, yang berdampak pada banyaknya kebutuhan sektor industri terhadap seorang penerjemah.

Pada hakikatnya kemampuan dasar yang seharusnya dimiliki seorang penerjemah adalah penguasaan bahasa sumber dan bahasa sasaran secara baik, namun masih ada beberapa hal lain yang perlu untuk diperhatikan agar menjadi seorang penerjemah yang 
mumpuni. Nababan (2008:11) membahasa mengenai pendapat beberapa pakar penerjemah yang sepakat bahwa seorang penerjemah harus memiliki pengetahuan untuk menerjemahkan, pengetahuan yang dimaksud adalah pengetahuan deklarasi dan pengetahuan prosedural (Schaffner \& Adab, 2000; Anderson, 1983 dalam PACTE, 2000), pengetahuan deklaratif adalah pengetahuan yang harus dikuasai oleh penerjemah sebelum menerjemahkan, sedangkan pengetahuan prosedural adalah pengetahuan yang berisi mengenai bagaimana cara menggunakan pengetahuan deklaratif atau langkah yang diambil penerjemah dalam proses penerjemahan.

PT Jiale Indonesia Textile yang berada di Jepara Indonesia, merupakan salah satu perusahaan yang bergerak di bidang tekstil. Perusahaan ini merupakan anak perusahaan dari Shanghai Jiale Corporation Limited, yang banyak mendatangkan ekspatriart dari negara Tiongkok yang masih belum terlalu menguasai bahasa Indonesia. Hal ini berdampak pada dibutuhkannya jasa penerjemah, namun kemampuan para penerjemah di perusahaan tersebut masih perlu untuk ditingkatkan, karena sering terjadi kurang berterimanya hasil penerjemahan. Seperti yang dibahas oleh Winantu Kurnianingtyas S. A. (2008,p. 17-19) dalam thesis nya yang berjudul Kualitas Hasil Penerjemahan Individu dan Penerjemahan Kelompok (Studi Kasus Proses dan Hasil Penerjemahan Mahasiswa Pascasarjana Program Studi Linguistik Minat Utama Penerjemahan UNS), beliau merangkum ada 6 klasifikasi kompetensi yang seharusnya dimiliki oleh seorang penerjemah, yaitu:

a. Kompetensi Linguistik

Seorang penerjemah harus memiliki kompetensi linguistik, karena tugas penerjemah adalah mentransfer atau menerjemahkan teks dari satu bahasa ke bahasa lain, dan kemampuan linguistik ini sangat vital karena dapat mempengaruhi kualitas hasil terjemahan.

b. Kompetensi Tekstual

Kompetensi ini mengharuskan seorang penerjemah mengenali dan memahami beragam jenis teks dan dapat menerjemahkan jenis teks tersebut dengan teknik yang sesuai. c. Kompetensi Domain/Subject Spesific

Kompetensi domain/subject spesific berbicara tentang seorang penerjemah dalam menguasai materi teks yang akan diterjemahkan. Setidaknya penerjemah dapat mengerti dan memahami domain/subject dari teks tersebut.

d. Kompetensi Kultural

Penerjemah dalam kompetensi ini harus menguasai budaya kedua bahasa, dengan 
adanya kemampuan atau kompetensi ini maka penerjemah dapat dengan mudah mencari padanan kata atau istilah dengan pengetahuan budaya yang luas, serta penerjemah dapat dengan mudah meminimalisir kerancuan kosakata yang baru dikenal.

e. Kompetensi Riset

Kemampuan atau kompetensi penerjemah dalam memecahkan permasalahan yang terkait dengan pengambilan keputusan dalam kegiatan penerjemahan, seperti struktur bahasa.

\section{f. Kompetensi Transfer}

Kemampuan atau kompetensi penerjemah untuk mengalihkan pesan dari suatu bahasa sumber ke dalam bahasa sasaran dimana penerjemah harus mempertahankan makna sekaligus mengungkapkan makna dengan tepat dan jelas ke dalam bahasa sasaran.

Keenam kompetensi di atas merupakan rangkuman pendapat dari beberapa para ahli penerjemahan. Masih ada banyak jenis kompetensi-kompetensi yang harus dimiliki oleh seorang penerjemah menurut beberapa para ahli yang menjadi standar kompetensi bagi seorang penerjemah, namun para ahli penerjemah memiliki satu kesamaan konsep, bahwa seorang penerjemah tidak seharusnya hanya memiliki kompetensi bahasa yang baik, namun juga harus dapat memiliki dan mengembangkan kompetensi diri lainnya.

Nida dan Taber (1982:33-34) juga berpendapat bahwa penerjemahan harus melewati 3 proses yaitu analisis (analysis), pengalihan (transfer) dan proses penyusunan kembali (restructing), dari 3 proses tersebut dapat dijelaskan bahwa:

a. Analisis (Analysis)

Proses analisis ini penerjemah membaca berulang kali teks sumber untuk dapat mengenali isi, ide, atau pesan dari teks sumber, gaya bahasa, jenis teks, dan gramatikal bahasa agar makna dalam teks dapat teridentifikasi dengan baik.

b. Pengalihan (Transfer)

Saat proses pengalihan, penerjemah mulai mengalihkan isi, ide, atau pesan dari Bahasa Sumber ke dalam Bahasa Sasaran. Proses ini penerjemah harus menemukan padanan kata yang tepat, sehingga hasil terjemahan akan lebih baik.

c. Penyusunan Kembali (Restructing)

Proses penyusunan kembali atau Restructing ini penerjemah menulis kembali terjemahan yang telah dilakukan dengan menyesuaikan gaya bahasa dan tata bahasa atau budaya yang ada pada Bahasa Sasaran sehingga menghasilkan terjemahan yang baik, tidak kaku, dan dapat diterima.

Menurut Larson (1984: 532) untuk menentukan kualitas penerjemahan, kita dapat 
membaginya dengan 3 aspek yaitu keakuratan, kejelasan, dan kealamiahan. Kualitas penerjemahan seorang penerjemah dapat dilihat dari aspek keakuratan dalam terjemahannya. Dalam aspek keakuratan ini seorang penerjemah harus yakin mengenai terjemahannya memiliki keakuratan makna atau tidak, pesan yang harus disampaikan. Aspek kejelasan adalah aspek penting, karena kejelasan terjemahan akan dinilai oleh pembaca, jika informasi tersampaikan dengan baik maka kejelasan penerjemahan sudah dapat diterima. Terakhir aspek kealamiahan aspek ini memiliki beberapa poin penting bagi penerjemah agar terjemahan yang dihasilkan memiliki kealamiahan yang baik yaitu poin gaya bahasa dan tata bahasa yang baik akan membuat terjemahan yang dihasilkan memiliki kewajaran dan mudah untuk diterima oleh pembaca.

Selain kompetensi, proses penerjemahan, seorang penerjemah harus memiliki perbendaharaan kosakata yang beragam dan bervariasi. Seorang penerjemah juga harus cekatan dalam memilih kosakata yang tepat dalam proses penerjemahan terutama seorang interpreter, yang hanya mempunyai waktu singkat untuk menerjemahkan dari bahasa sumber ke bahasa sasaran. Banyak penerjemah baru yang kesulitan dalam memahami kosakata dalam bidang tertentu, seperti pada bidang industri tekstil. Salah satu cara yang dapat digunakan untuk mempermudah mempelajari kosakata bidang tertentu, kita bisa mengklasifikasikannya dengan membagi sesuai dengan jenis kata.

Kosakata sendiri memiliki banyak arti atau pengertian, salah satunya menurut Gorys Keraf (2006: 80) kosakata adalah keseluruhan kata yang berada dalam ingatan seseorang, yang akan segera menimbulkan reaksi bila didengar atau dibaca. Ada 10 jenis kata yang sudah familiar dalam kehidupan kita, yaitu (a) Kata Kerja (b) Kata Ganti (c) Kata Benda (d) Kata Bilangan (e) Kata Sifat (f) Kata Keterangan (g) Kata Sandang (h) Kata Depan (i) Kata Penghubung (j) Kata Seru.

\section{B. Metode Penelitian}

Penelitian ini merupakan penelitian deskriptif kualitatif dengan objek penelitian adalah para penerjemah perusahaan tekstil bahasa Mandarin-Indonesia, Indonesia-Mandarin, serta kosakata bahasa Mandarin yang sering digunakan pada bidang tekstil PT Jiale Indonesia Textile yang berdomisili di Jepara, Jawa Tengah. Metode analisis data dimulai dari pengumpulan data yang dilakukan dengan membaca, menyimak, mengidentifikasi kebutuhan seorang penerjemah yang dilihat dari kebutuhan kompetensi, dan yang terakhir mengklasifikasi istilah bidang tekstil. 


\section{Hasil dan Pembahasan}

\section{Kebutuhan Seorang Penerjemah Berdasarkan Kompetensi}

Kebutuhan seorang penerjemah dalam proses penerjemahan dapat dilihat dari 2 hal yaitu: kebutuhan internal dan kebutuhan eksternal. Pada bagian kebutuhan internal dapat dilihat dari dalam diri seorang penerjemah atau dapat dilihat dari kemampuan pribadi penerjemah, untuk dapat meningkatkannya seorang penerjemahan tidak hanya dapat mempunyai kemampuan dalam pemilihan kosakata, struktur kalimat, namun juga metode yang digunakan penerjemah dalam proses penerjemahan sangat mempengaruhi hasil penerjemahan, kemampuan penerjemah ini biasa disebut dengan kompetensi penerjemah. Pada bagian eksternal dapat dilihat dari luar diri pribadi seorang penerjemah dimana alat atau media yang digunakan untuk membantu proses penerjemahan yang dilakukan, media yang dimaksud seperti google terjemahan, pleco, dan kamus elektronik maupun buku.

\subsection{Kompetensi Penerjemahan}

Seperti yang telah dibahas dalam pada bab pendahuluan, menurut Winantu Kurnianingtyas ada 6 kompetensi penerjemah yang harus dikuasai oleh penerjemah selain penguasaan bahasa sumber dan bahasa sasaran. Kompetensi tersebut yaitu kompetensi linguistik, tekstual, domain/subject spesific, kultural, riset, dan transfer. Berdasarkan hasil observasi dan survei di lapangan, penerjemah yang ada di PT Jiale Indonesia Textile, sering kurang menguasai kompetensi domain/Subject spesific, riset dan transfer. Kurangnya penguasaan kompetensi ini dapat mempengaruhi hasil terjemahan.

\section{Kompetensi Domain/Subject Specific}

Kompetensi ini mengharuskan penerjemah untuk menguasai materi teks yang akan diterjemahkan. Setidaknya penerjemah dapat mengerti dan memahami domain/subject specific dari teks tersebut. Jika penerjemah tidak dapat menguasai subjek dari teks yang akan diterjemahkan atau tidak dapat mengerti dan memahami teks yang akan diterjemahkan, maka hasil teks yang dihasilkan akan kurang berterima seperti contoh di bawah ini diambil dari dokumen mengenai quality control:

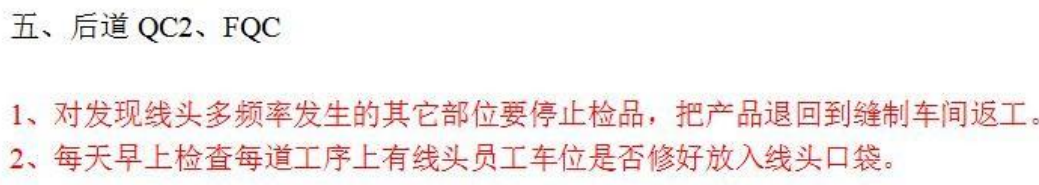

Gambar 1. Quality Control, Fquality control 
袋。”, salah seorang penenrjemah menerjemahkannya menjadi “memeriksa pekerja yang membuat kepala benang setiap pagi, apakah pekerja memotong kepala benang dan memasukkan kepala benang ke dalam saku kepala benang." Pada contoh di atas kata “线 头 " xiàntóu diartikan menjadi "kepala benang", penerjemah menerjemahkan kata “线头” secara harfiah menjadi "kepala benang" yang menjadikan terjemahan kurang berterima. Sedangkan menurut penjelasan yang diberikan oleh TKA asal Tiongkok mengenai kata “线 头” memiliki arti yaitu "benang timbul/benang sisa" terjemahan akan lebih berterima, jika penerjemah dapat memahami teks, dan setiap kosakata pada teks. Terjemahan akan lebih baik jika diubah menjadi "setiap pagi periksa pekerja yang membuat thread ends / benang timbul, apakah mereka memotongnya dan menempatkannya pada saku benang timbul."

2. Kompetensi Riset

Kompetensi penerjemah dalam memecahkan permasalahan yang terkait dengan pengambilan keputusan dalam kegiatan penerjemahan, seperti struktur bahasa.

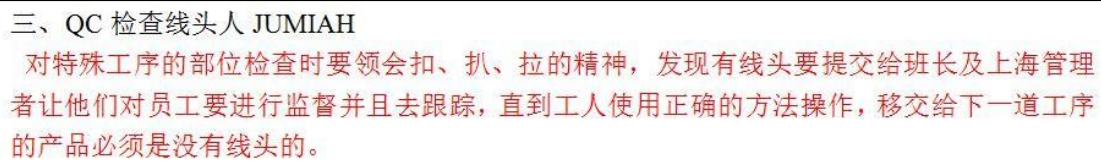

Gambar 2. Quality Control

Pada kalimat “对特殊工序的部位检查时要领会扣、扒、拉的精神，发现有线 头要提交给班长及上海管理者让他们对员工要进行监督并且去跟踪, 直到工人使用 正确的方法操作，移交给下一道工序的产品必须是没有线头的。”, seorang penerjemah, menerjemahkannya menjadi "Ketika memeriksa bagian-bagian dari proses khusus, kita harus memahami semangat tekuk, memetik, dan menarik, dan menemukan bahwa kepala benang harus diserahkan kepada monitor dan manajer Shanghai agar mereka mengawasi dan melacak karyawan sampai pekerja menggunakan metode yang benar untuk mengoperasikan dan mentransfernya ke yang berikutnya Produk dari satu proses harus bebas dari kepala benang. Terjemahan yang dihasilkan memiliki arti secara harafiah, dengan menerjemahkan “要领会扣、扒、拉的精神” yang secara harafiah diterjemahkan menjadi "harus memahami semangat tekuk, memetik, dan menarik". Seorang penerjemah harus memiliki wawasan luas dan penguasaan isi/makna teks.

Penerjemah berusaha mempertahankan makna asli, namun hasil terjemahan yang dihasilkan kurang dapat diterima. Penting untuk mempertahankan makna, namun untuk 
struktur bahasa sasaran kurang dapat dimengerti.

Terjemahan akan lebih baik jika diubah menjadi "Saat memeriksa bagian proses jahit khusus, quality control perlu mempelajari Kebijakan Manajemen thread ends/benang timbul. Jika kami menemukan benang timbul, kami akan melaporkan kepada pemimpin tim dan manajer Shanghai. Pemimpin tim dan manajer Shanghai akan melatih para pekerja dan memastikan para pekerja memiliki keterampilan yang baik \& benar untuk menangani thread ends/benang timbul sehingga prosedur selanjutnya dapat berjalan dengan lancar tanpa thread ends/benang timbul.” . Pada bagian “要领会扣、扒、拉的精神” dapat diterjemahkan menjadi "quality control perlu mempelajari kebijakan manajemen thread ends/benang timbul" karena konteks yang ada dalam teks tersebut mengenai divisi quality control dan terjemahan ini dapat lebih dimengerti dan diterima.

\section{Kompetensi Transfer}

Kompetensi Transfer adalah kompetensi untuk mengalihkan pesan dari suatu bahasa sumber ke dalam bahasa sasaran dimana penerjemah harus mempertahankan makna sekaligus mengungkapkan makna dengan tepat dan jelas ke dalam bahasa sasaran.

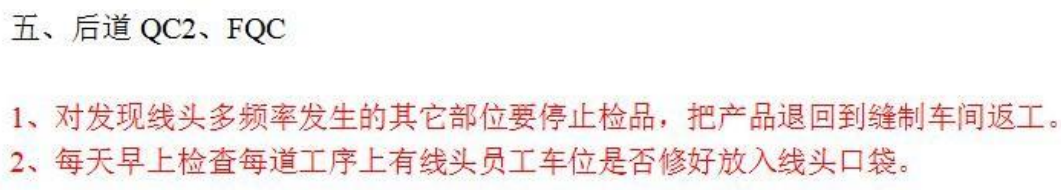

Gambar 3. Quality Control, Fquality control

Pada kalimat “对发现线头多频率发生的其他部位要停止检品，把产品退回到 缝制车间返工。”, seorang penerjemah, menerjemahkannya menjadi “Terhadap terjadinya kemunculan banyak kepala benang, bagian yang lain harus berhenti memeriksa, barang akan dikembalikan.”. Terjemahan tersebut dapat diterima, akan tetapi untuk struktur bahasa yang digunakan kurang tepat, dengan kehadiran partikel “的” kalimat di atas sebenarnya memberitahukan bahwa "Berhenti inspeksi bagian lain, jika menemukan banyak thread ends/benang timbul, garment/baju akan dikembalikan ke sewing line untuk diperbaiki" dalam hal ini penerjemah tidak menerjemahkan dengan struktur kalimat yang rinci, yang sebenarnya kalimat ini berisi tentang himbauan, jika penerjemah hanya menerjemahkan beberapa, maka akan mudah terjadi salah paham.

\subsection{Media Pendukung Proses Penerjemahan}

Saat proses penerjemahan seringkali memerlukan media bantu untuk memperlancar dan mempermudah proses penerjemahan. Berdasarkan hasil observasi, proses penerjemah 
yang ada di PT Jiale Indonesia Textile lebih sering menggunakan media bantu berupa kamus online, seperti google terjemahan dan Pleco untuk membantu proses penerjemahan, namun adakalanya seorang penerjemah dihadapkan pada kondisi tidak dapat untuk setiap saat membuka gawainya saat bekerja, jadi yang dapat dipersiapkan oleh seorang penerjemah adalah mempelajari terlebih dahulu kosakata yang berhubungan dengan bidang yang mereka pegang. Alat bantu yang dimaksud untuk dapat dipelajari adalah catatan/daftar kosakata. Para penerjemah dapat membawa dan menggunakan daftar kosakata untuk membantu proses penerjemahan.

\section{Daftar Istilah Kosakata Bidang Industri Tekstil}

Daftar kosakata ini didapat dari hasil observasi dan melalui proses penerjemahan 3 tahap seperti yang diungkapan oleh Nida dan Taber dalam judul "The Theory and Practice of Translation" yaitu berupa analisis, pengalihan, dan restructing atau penyusunan kembali. Daftar istilah kosakata dikelompokkan menjadi 3 jenis kata, kata sifat (adjective), kata benda (noun), dan kata kerja (verb).

Tabel 1.

Daftar Istilah Kosakata Bidang Industri Tekstil

\begin{tabular}{|c|c|c|c|c|}
\hline No & 生词打样间 & 词类 & 拼音 & 意思 \\
\hline 1 & 薄 & $\mathrm{Adj}$ & báo & Tipis \\
\hline 2 & 对称 & Adj & duìchèn & Simetri \\
\hline 3 & 合格 & Adj & hégé & Memenuhi syarat \\
\hline 4 & 厚 & Adj & hòu & Tebal \\
\hline 5 & 宽 & Adj & kuān & Lebar \\
\hline 6 & 门幅 & Adj & ménfú & Lebar kain \\
\hline 7 & 软 & Adj & ruăn & Lembut \\
\hline 8 & 长 & Adj & cháng & Panjang \\
\hline 9 & 皱 & Adj & zhòu & Kusut \\
\hline 10 & 歪 & Adj & wāi & Miring \\
\hline 11 & 对称 & Adj & duìchèn & Simetris \\
\hline 12 & 包材 & Noun & bāocái & Bahan kemasan \\
\hline 13 & 备注 & Noun & bèizhù & Catatan \\
\hline 14 & 波浪 & Noun & bōlàng & Gelombang \\
\hline 15 & 尺寸 & Noun & chǐcùn & Ukuran $(\mathrm{cm}, \mathrm{m}, \mathrm{mm})$, \\
\hline 16 & 锋头 & Noun & fēngtóu & Meneruskan \\
\hline 17 & 缝线 & Noun & féngxiàn & Jahitan \\
\hline 18 & 缸号 & Noun & gānghào & Nomor kain \\
\hline 19 & 规格 & Noun & guīgé & Spesifikasi \\
\hline 20 & 货号 & Noun & huòhào & Kode Produk \\
\hline
\end{tabular}




\begin{tabular}{|c|c|c|c|c|}
\hline 21 & 胶袋 & Noun & jiāodài & Kantong plastic \\
\hline 22 & 胶筐 & Noun & jiāokuāng & Keranjang plastic \\
\hline 23 & 客户 & Noun & kèhù & Klien \\
\hline 24 & 口袋 & Noun & kǒudai & Saku \\
\hline 25 & 拉链 & Noun & lāliàn & Resleting \\
\hline 26 & 拉索 & Noun & lāsuǒ & Laso \\
\hline 27 & 连口 & Noun & liánkǒu & Sambungan Jahitan \\
\hline 28 & 领条 & Noun & lǐngtiáo & Kerah \\
\hline 29 & 帽子 & Noun & màozi & Topi/Hoodie \\
\hline 30 & 面料 & Noun & miànliào & Kain \\
\hline 31 & 浓度 & Noun & nóngdù & Ketebalan \\
\hline 32 & 匹号 & Noun & pǐhào & Roll Number \\
\hline 33 & 误差 & Noun & wùchā & Kesalahan \\
\hline 34 & 洗唛 & Noun & xĭmà & Washing Tag \\
\hline 35 & 下摆 & Noun & xiàbăi & Bagian Bawah Baju \\
\hline 36 & 限度 & Noun & xiàndù & Pembatas \\
\hline 37 & 线头 & Noun & xiàntóu & Benang \\
\hline 38 & 箱袋 & Noun & xiāngdài & Box \\
\hline 39 & 袖口 & Noun & xiùkǒu & Mulut Lengan \\
\hline 40 & 颜色 & Noun & yánsè & Warna \\
\hline 41 & 样板 & Noun & yàngbăn & Templat Baju \\
\hline 42 & 样衣 & Noun & yàngȳ̄ & Contoh Baju \\
\hline 43 & 纸箱 & Noun & zhǐxiāng & Kardus karton \\
\hline 44 & 质量 & Noun & zhìliàng & Kualitas \\
\hline 45 & 门襟 & Noun & ménjīn & Plaket \\
\hline 46 & 门襟上口 & Noun & ménjīnshàngkǒu & Mulut plaket atas \\
\hline 47 & 油污 & Noun & yóuwū & Noda Minyak \\
\hline 48 & 水渍 & Noun & shuǐzì & Spot Air \\
\hline 49 & 羿色 & Noun & yìsè & Perubahan Warna \\
\hline 50 & 送货单 & Noun & sònghuòdān & Surat Jalan \\
\hline 51 & 手警告 & Noun & shǒujǐnggào & SP/ Surat Peringatan \\
\hline 52 & 穿杆 & Noun & chuāngăn & Tali hangtag \\
\hline 53 & 落料 & Noun & luòliào & Kain ekspos/lebih \\
\hline 54 & 参数 & Noun & cānshù & Parameter \\
\hline 55 & 脱毛 & Noun & tuōmáo & Bulu rontok \\
\hline 56 & 领形 & Noun & lǐngxíng & Bentuk kerah \\
\hline 57 & 袖笼 & Noun & xiùlóng & Lengan baju \\
\hline 58 & 事项 & Noun & shìxiàng & Hal-hal \\
\hline 59 & 形状 & Noun & xíngzhuàng & Bentuk \\
\hline 60 & 改善 & Verb & găishàn & Memperbaiki/Merubah \\
\hline 61 & 测 & Verb & cè & Mengukur \\
\hline 62 & 确认 & Verb & quèrèn & Konfirmasi \\
\hline
\end{tabular}




\begin{tabular}{|c|c|c|c|l|}
\hline 63 & 审核 & Verb & shěnhé & Audit \\
\hline 64 & 洗 & Verb & xǐ & Mencuci \\
\hline 65 & 下降 & Verb & xiàjiàng & Menurun \\
\hline 66 & 压缩 & Verb & yāsuō & Kompresi/Tekanan \\
\hline 67 & 压线 & Verb & yāxiàn & Ditindas \\
\hline 68 & 整理 & Verb & zhěnglǐ & Mengelompokkan \\
\hline 69 & 打印 & Verb & dǎyìn & Print \\
\hline 70 & 扫 & Verb & săo & Scan \\
\hline 71 & 缩水 & Verb & suōshuř & Menyusut \\
\hline 72 & 划伤 & Verb & huáshāng & Menggores \\
\hline 73 & 评估 & Verb & pínggū & Evaluasi \\
\hline 74 & 依赖 & Verb & yīlài & Bergantung \\
\hline 75 & 吊 & Verb & diào & Menggantung \\
\hline 76 & 反映 & Verb & fãnyìng & Tercermin \\
\hline
\end{tabular}

\section{Kesimpulan}

Berdasarkan pembahasan di atas mengenai apa saja kebutuhan seorang penerjemah, dan kurangnya kompetensi penerjemah di PT Jiale Indonesia Textile dapat kita simpulkan bahwa untuk menjadi seorang penerjemah disebuah perusahaan tekstil seperti PT Jiale Indonesia Textile, tidak hanya mengandalkan penguasaan bahasa sumber dan bahasa sasaran yang baik, namun juga harus dapat menguasai dan meningkatkan diri, seperti: 1.Kompetensi Domain/Subject Specific; 2.Kompetensi Riset; 3.Kompetensi Transfer, setidaknya dengan memiliki dan meningkatkan ketiga kompetensi ini, dapat meningkatkan kualitas diri penerjemah dan akan berpengaruh besar terhadap kualitas hasil terjemahan. Disamping meningkatkan ketiga kompetensi tersebut, seorang penerjemah juga harus dapat menguasai media bantu dalam proses penerjemahan, seperti Google Terjemahan, Pleco, Kamus Online lainnya, maupun Kamus Offline seperti kamus Indonesia-Tionghoa; Tionghoa-Indonesia terbitan Dian Rakyat memang dapat membantu proses penerjemahan, namun akan lebih baik jika seorang penerjemah sudah siap dengan catatan atau daftar istilah kosakata dalam bidang mereka.

\section{Daftar Pustaka}

A.,Winantu Kurnianingtyas S., 2008, Kualitas Hasil Penerjemahan Individu dan PenerjemahanKelompok (Studi Kasus Proses dan Hasil Penerjemahan Mahasiswa Pascasarjana Program Studi Linguistik Minat Utama Penerjemahan Universitas Sebelas Maret Surakarta), Tesis, Pascasarjana Program Studi Linguistik, Universitas Sebelas Maret, Surakarta. 
Brill Larson, Mildred. (1984). Meaning Based Translation: A Guide to Cross Language Equivalence. Boston: University Press of America Inc.

Gorys Keraf. (2006). Diksi dan Gaya Bahasa. Jakarta: Gramedia.

Nababan, M.R. Teori Menerjemahkan Bahasa Inggris. 2008. Yogyakarta: Pustaka Pelajar.

Nida, Eugene A. dan Taber, Charles R. 1982. The Theory and Practice of Translation. Leiden: E.J.

王仲尔， 2009 年(10): 66 页，从词汇学角度看上市公司品牌翻译策略，上海金融学院

Catatan:

Artikel pernah dipresentasikan pada Seminar Nasional APSMI 24 Oktober 2020 